\title{
2000 years of climate variability inferred from Arctic lake
} sediments

Darrell S. Kaufman

Department of Geology, Northern Arizona University, Flagstaff, USA; Darrell.Kaufman@nau.edu

\section{A compilation of 14 new proxy records from Arctic lake sediments documents late Holocene climate and environmental change across North America and northwest Europe.}

\section{New records from Arctic lakes}

"PAGES-Arctic2k" (www.pages-igbp.org/ science/arctic $2 \mathrm{k} /$ ) was launched in March 2008 to generate new high-resolution paleoclimate records for investigating Arctic climate change during the past two millennia. As a contribution to the Arctic2k initiative and to the International Polar Year, a group of Arctic paleoscientists focusing on lake sediments recently completed a special issue of the Journal of Paleolimnology. The 14 papers report new records of Holocene climate and environmental change from Arctic lakes, with an emphasis on the last $2 \mathrm{kyr}$. The compendium stems from the Arctic System Sciences (ARCSS) $2 \mathrm{kyr}$ project, which was funded in 2005 by the US National Science Foundation.

The journal volume represents a coordinated response to the pressing need for additional, high-quality proxy-climate records from high latitudes. The studies contribute to the long-term perspective on natural climate variability that is needed to understand historically unprecedented changes now occurring in the Arctic. They focus on lakes from across the N. American Arctic and NW Europe (Fig. 1; see also Gajewski et al., this issue). One of their overarching goals is to assess recent warming against the backdrop of the last two millennia. Records of this duration are needed to investigate the conditions prior to the last major cold interval-the Little Ice Age (LIA) - when most of the Arctic experienced the coldest temperatures of the last 8 kyr. Records of this duration are also the focus of other campaigns for paleoclimate research globally, ultimately providing the basis for a global synthesis of the climate of the last $2 \mathrm{kyr}$.

Lakes are widely distributed in the Arctic, and they contain the most accessible proxy records that consistently extend through the late Holocene and longer. A large network of proxy climate records is needed to capture the spatial variability of climatic change, and to study spatial patterns of atmospheric circulation at a synoptic scale.

Quantifying past climate from records in lakes is among the greatest challenges in paleolimnology. Absolute values of temperature, precipitation, and other variables are needed to gauge the magnitude

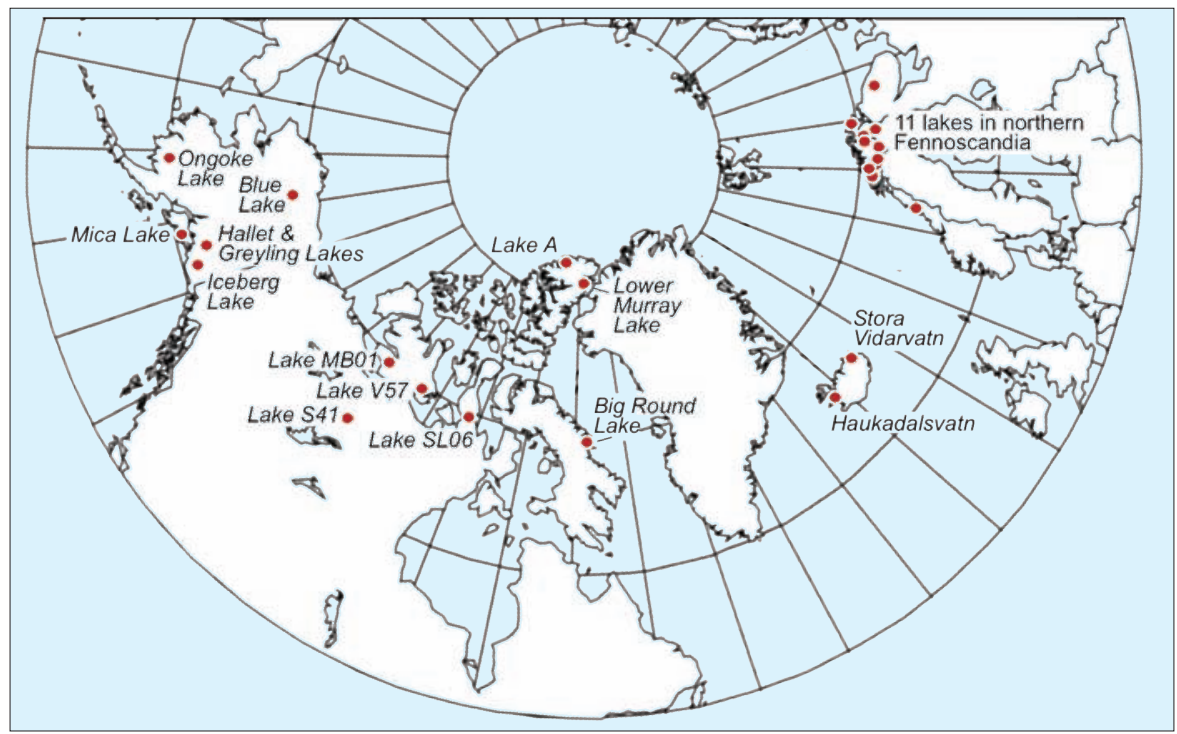

Figure 1: Location of lakes included in a new special issue of the Journal of Paleolimnology dedicated to reconstructing late Holocene climate and environmental change from Arctic lake sediments.

of past climate change and to compare with the output of climate-model simulations. The studies in the new compendium rely on multiple sedimentological and biological indicators that primarily reflect changes in summer temperatures, the main control on physical and biological processes in lakes at high latitudes. Some reflect other aspects of the climate system, including nutrient availability and winter storm-track trajectories.

\section{Results from proxy records}

Four of the studies in the volume used varve thickness from glacier-fed lakes to infer past summer temperatures. The strength of these records is their annual resolution and accurate timescale. Cook et al. generated a varve-inferred temperature record from Ellesmere Island that covers the past $5 \mathrm{kyr}$, making it the longest annually resolved lacustrine record from the Arctic. Bird et al. present the first annually resolved summer-temperature record from north of the treeline in northern Alaska. In southern Alaska, Loso developed a 1.3 kyr record, and in Baffin Island, Thomas and Briner reconstructed summer temperature for the past $1 \mathrm{kyr}$. On Ellesmere Island, Tomkins et al. used a novel sedimentary feature (sedimentary pellets) to interpret ice-cover extent.

Three papers focused on the use of chironomids to develop quantitative temperature records from both northern Canada (Porinchu et al., MacDonald et al.) and Iceland (Axford et al.), and two on the use of pollen for temperature reconstructions from Fennoscandia (Bjune et al.) and northern Canada (Peros and Gajewski). Additionally, Chipman et al. used diatoms to reconstruct lake-level fluctuations from SW Alaska. Sedimentation rates at sites suitable for these biological proxies are usually lower than in glacier-fed lakes, and time-averaging and sample-size requirements are relatively high. The resulting records typically have only centennial resolution but they extend back at least 2 kyr. Most of the temperature reconstructions based on these proxies show broad similarities with others averaged over the northern hemisphere.

Nine studies reported results of organic-matter and biogenic-silica analyses, which were mainly used as part of a multiproxy approach. McKay and Kaufman used the organic-matter content from two nearby glacier-fed lakes in south-central Alaska, together with geomorphologic evidence for late Holocene glacier fluctuations within the catchments, and their previously published biogenic-silica-inferred temperature record, to reconstruct relative changes in effective moisture. Geirsdóttir et al. showed that biogenic-silica content was correlated with spring/earlysummer temperature in Iceland, and they used organic-matter content to interpret the impact of landscape stability. Finally, Schiff et al. analyzed the oxygen-isotope composition of diatoms from a coastal 


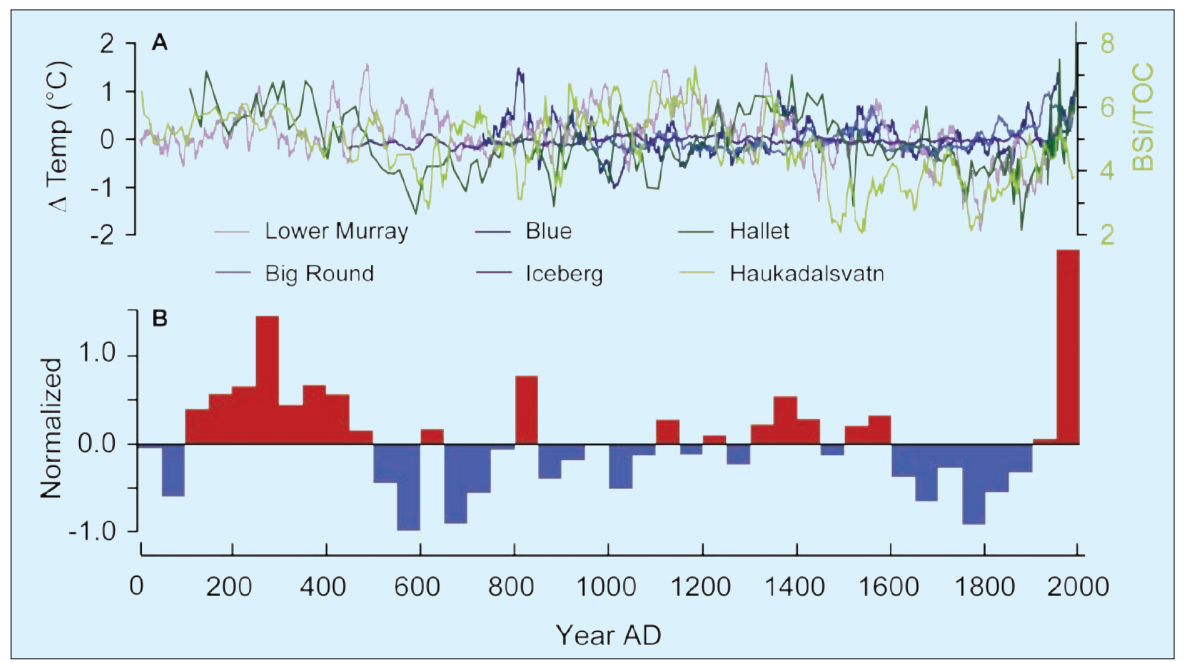

Figure 2: Summary of the 6 new proxy climate records from Arctic lakes with sub-decadal to annual resolution. $\boldsymbol{A}$ ) 5 records were calibrated using instrumental climate records to infer past summer temperature and are plotted as anomalies relative to the average of the last millennium ( $\triangle T$ Temp). 1 record (Haukadalsvatn) was not calibrated and is plotted according to the raw ratio of biogenic-silica to total-organic content (BSi/TOC); $\boldsymbol{B}$ ) The records were stacked by binning the data into 50-year intervals, normalizing each to a mean of zero and a variance of 10 , then averaging the values for each bin. The records include Lower Murray Lake (Cook et al.), Big Round Lake (Thomas and Briner), Blue Lake (Bird et al.), Iceberg Lake (Loso), Hallet Lake (McKay and Kaufman), and Haukadalsvatn (Geirsdóttir et al.).

lake in southern Alaska to infer changes in the trajectory of storm tracks in a region dominated by the influence of the Aleutian low-pressure system.

\section{High-resolution records}

Of the new proxy records, six are resolved at sub-decadal to annual scale, including four based on varve thicknesses and two on biogenic-silica content (Fig. 2). They were calibrated using instrumental climate records to develop regression models to infer numerical values of past summer temperature downcore. The temperature variation for these records averages $\pm 0.73^{\circ} \mathrm{C}(1 \sigma)$. Stacking the records by binning the data into 50 -year intervals, normalizing each to a mean of zero and a variance of $1 \sigma$, then averaging the values for each bin reveals a coherent structure to the time series. Most striking is the most recent half-century, which exhibits the single highest average normalized temperature values and a shift to higher temperatures that is twice as large as any other consecutive interval during the last 2 kyr. leoclimate archives. These will be used to investigate the spatial and temporal variability of climate change in the Arctic, and will be integrated into experiments using general circulation models. These data-model comparisons are aimed at distinguishing patterns of forced climate change from internal variability in the Arctic climate system. The effort will be part of the PAGES Arctic $2 k$ initiative and will be facilitated by data management provided through the World Data Center for Paleoclimatology (www.ncdc.noaa.gov/paleo/) and the PAGES Arctic2k Metadatabase (www.pages.unibe.ch/science/arctic2k/). More information about this project, including an overview of the climate-modeling component, is available at: www.arcus. org/synthesis $2 \mathrm{k} /$

\section{Acknowledgements}

I thank the authors of the 14 papers now in press in the Journal of Paleolimnology, and the 41 peer reviewers for their generous input. I thank $M$. Brenner and T. Whitmore for editorial support, N. McKay for data analysis, and the WDC for Paleoclimatology for data archival. Research and project coordination were funded primarily by the US-NSF Arctic System Science Program. (800-1600 AD) does not exhibit a coherent pattern of temperature fluctuations, nor evidence for a constantly warm Medieval period. Instead, 100-500 AD is the most protracted warm period. This result is based on only three proxy records that extend the full duration of the last $2 \mathrm{kyr}$ but is consistent with the first-order trend of overall cooling that is exhibited by the lower-resolution records reported by other papers in the special issue. It also suggests that as new high-resolution proxy records are generated, a warm interval more pronounced than during Medieval times will emerge as a prominent feature of Arctic climate during the first millennium AD.

\section{Future plans}

In the future, the new lacustrine proxy records will be integrated into a larger network of sites that includes other pa-

\section{References}

Bird, B.W., Abbott, M.B., Finney, B.P. and Kutchko, B., in press: A 2000 year varve-based climate record from the central Brooks Range, Alaska, Journal of Paleolimnology, 41 (1): Jan. 2009.

Cook, T., Bradley, R.S., Stoner, J.S. and Francus, P., in press: Five thousand years of sediment transfer in a High Arctic watershed recorded in annually laminated sediments from Lower Murray Lake, Ellesmere Island, Nunavut, Canada, Journal of Paleolimnology, 41(1): Jan. 2009.

Geirsdóttir, A., Miller, G.H., Thordarson, T. and Ólafsdóttir, K.B., in press: A 2000 year record of climate variations reconstructed from Haukadalsvatn, west Iceland, Journal of Paleolimnology, 41(1): Jan. 2009. Period and Little Ice Age inferred from varved proglacial lake sediments in southern Alaska, Journal of Paleolimnology, 41(1): Jan. 2009.

McKay, N.P. and Kaufman, D.S., in press: Holocene climate and glacier variability at Hallet and Greyling Lakes, Chugach Range, southcentral Alaska, Journal of Paleolimnology, 41(1): Jan. 2009.

Thomas, E.K. and Briner, J.P., in press: Climate of the past millennium inferred from varved proglacial lake sediments, northeast Baffin Island, Arctic Canada, Journal of Paleolimnology, 41(1): Jan. 2009.

For full references please consult:

www.pages-igbp.org/products/newsletters/ref2009_1.html
Loso, M.G., in press: Summer temperatures during the Medieval Warm

\section{Holocene paleoclimate of the Canadian Arctic Islands: The ACVAST project}

Konrad Gajewski ${ }^{1}$, M. Peros ${ }^{1}$, S. Finkelstein ${ }^{2}$ and M. Fortin ${ }^{1}$

'Department of Geography and Ottawa-Carleton Institute of Biology, University of Ottawa, Canada; gajewski@uottawa.ca; Department of Geography, University of Toronto, Canada

Multi-proxy studies of a series of lakes across the Canadian Arctic Islands are providing the first continuous and quantitative estimates of Holocene climate variability for the region. These reconstructions highlight the impact of climate variations on biological production and biodiversity in Arctic ecosystems.

Arctic ice cores provide critical records of Holocene climate variability. However, to map the spatial patterns of past climates and explain local ecological responses to climate variability, an extensive array of sites is needed. Continuous records from lake sediments provide a major source of information toward this goal. 